\title{
Seasonal changes in gaseous elemental mercury in relation to monsoon cycling over the northern South China Sea
}

\author{
C. M. Tseng ${ }^{1}$, C. S. Liu ${ }^{1}$, and C. Lamborg ${ }^{2}$ \\ ${ }^{1}$ Institute of Oceanography, National Taiwan University, P.O. Box 23-13, Taipei 106, Taiwan, China \\ ${ }^{2}$ Woods Hole Oceanographic Institute, MS 51, Woods Hole, MA 02543, USA \\ Correspondence to: C. M. Tseng (cmtseng99@ntu.edu.tw)
}

Received: 17 April 2012 - Published in Atmos. Chem. Phys. Discuss.: 11 May 2012

Revised: 19 July 2012 - Accepted: 6 August 2012 - Published: 16 August 2012

\begin{abstract}
The distribution of gaseous elemental mercury (GEM) was determined in the surface atmosphere of the northern South China Sea (SCS) during 12 SEATS cruises between May 2003 and December 2005. The sampling and analysis of GEM were performed on board ship by using an on-line mercury analyzer (GEMA). Distinct annual patterns were observed for the GEM with a winter maximum of $5.7 \pm 0.2 \mathrm{ng} \mathrm{m}^{-3}(n=3)$ and minimum in summer $(2.8 \pm 0.2 ; n=3)$, with concentrations elevated $2-3$ times global background values. Source tracking through backward air trajectory analysis demonstrated that during the northeast monsoon (winter), air masses came from Eurasia, bringing continental- and industrial-derived GEM to the SCS. In contrast, during summer southwest monsoon and inter-monsoon, air masses were from the Indochina Peninsula and Indian Ocean and west Pacific Ocean. This demonstrates the impact that long-range transport, as controlled by seasonal monsoons, has on the $\mathrm{Hg}$ atmospheric distribution and cycling in the SCS.
\end{abstract}

\section{Introduction}

Mercury $(\mathrm{Hg})$ is a neurotoxic pollutant that poses a threat to human health via the consumption of fish and fish products (Lindqvist et al., 1991; Fitzgerald and Clarkson, 1991). In contrast to other metals, $\mathrm{Hg}$ is a relatively volatile, which allows it to be transported to Earth's biologically active reservoirs via the atmosphere. Gaseous elemental $\mathrm{Hg}$ (GEM), the predominant form of atmospheric $\mathrm{Hg}\left(\mathrm{Hg}^{0},>95 \%\right.$ of total) is very stable with an atmospheric residence time of several months to 1 year (Selin et al., 2008; Holmes et al., 2010;
Soerensen et al., 2010). This enables Hg to undergo long range transport and hence, becomes well-mixed on a global scale (Fitzgerald et al., 1998, 2005). Globally, Hg emissions and presumably $\mathrm{Hg}^{0}$ concentrations have increased significantly as a result of human activities and represent about $60 \%$ of the total atmospheric emissions (Mason et al., 1994; Lamborg et al., 2002). About half of global anthropogenic emissions $\left(\sim 2500 \mathrm{t} \mathrm{yr}^{-1}\right)$ are estimated to come from Asia and this sector is expected to increase in dominance due to the rapidly expanding economies of East Asia, particularly Mainland China, and their use of high-sulfur and -mercury, domestic coal (Pacyna et al., 2003, 2006; Wang et al., 2000; Wu et al., 2006, Streets et al., 2009). Higher Hg emissions result in elevated atmospheric concentration and high deposition levels (Swain et al., 1992; Guo et al., 2008). This may represent a potential threat to the East Asian region and the globe with respect to environmental impact and public health (Friedli et al., 2004; Jaffe et al., 2005; Strode et al., 2008; Obrist et al., 2008). Therefore, studies on Hg source attribution and the scale of current and future anthropogenic perturbations within East Asia and its surrounding marginal seas (e.g., East China Sea (ECS), South China Sea (SCS)) are urgently needed.

Some studies on atmospheric $\mathrm{Hg}$ cycling over the East Asian marginal seas were previously made (Sprovieri et al., 2010). For example, in the Northwest Pacific Ocean near Japan in 2002, GEM varied from about 1.6 to $4.7 \mathrm{ng} \mathrm{m}^{-3}$ (Laurier et al., 2003) and 1.6 to $6.3 \mathrm{ng} \mathrm{m}^{-3}$ (Friedli et al., 2004) and 1.4-4.7 $\mathrm{ng} \mathrm{m}^{-3}$ (Jaffe et al, 2005) in seas near Korea and Japan, respectively. Furthermore, elevated GEM concentrations $\left(\sim 3-6.3 \mathrm{ng} \mathrm{m}^{-3}\right)$ in the ESC and North Pacific Ocean were linked to the export of $\mathrm{Hg}$ enriched air masses 


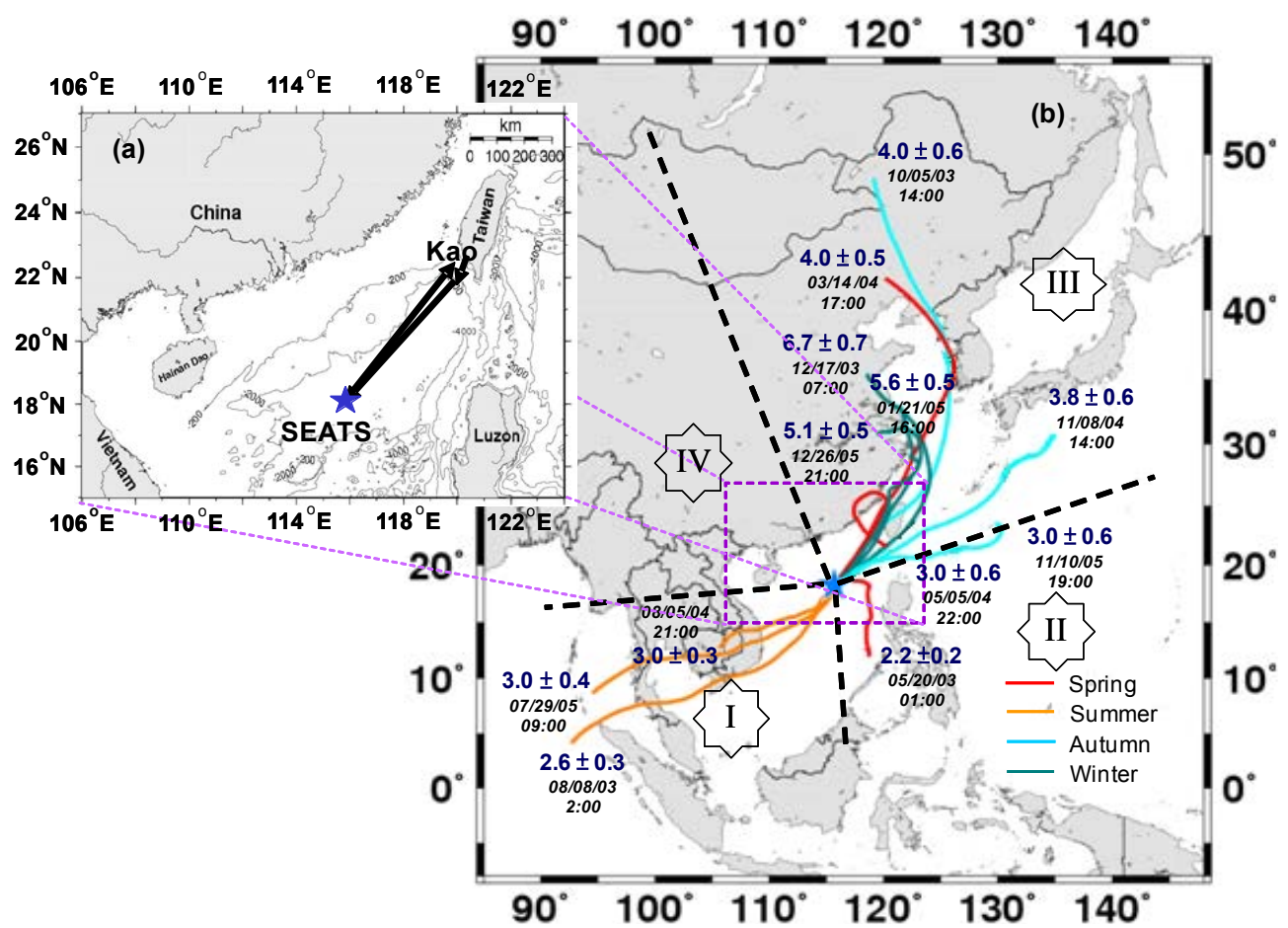

Fig. 1. (a) Sampling site of the South-East Asian Time-series Study (SEATS) station in the northern South China Sea (SCS) with routine cruise tracks (arrow) between the Kaoshiung (kao) and the SEATS station (star); (b) the 3-day backward trajectories started at the mid-way time of the cruise at the SEATS station with average GEM concentrations and marked four general air-advection groups: (I) Southwest monsoon with prevailing SW wind; (II) Inter-monsoon and others (e.g., typhoon) with ENE-E-S wind sector; (III) Northeast monsoon with prevailing NE wind and (IV) air masses from south China with E-NW wind sector.

from eastern China (Friedli et al., 2004). In addition to northern SCS, similar summer average GEM concentrations in August were also recently reported $2.7 \pm 0.8$ (Tseng et al., 2010) and $2.6 \pm 1.1 \mathrm{ng} \mathrm{m}^{-3}$ (Fu et al., 2010) in 2003 and 2007 , respectively. Further, higher GEM in winter and lower in late spring and summer 2003 were observed which may be linked to the increasing export of $\mathrm{Hg}$ from China to SCS during the cold season (Tseng et al., 2010). Those results suggested seasonal GEM variations over the northern SCS were related to the supply and source of GEM controlled by the East Asian monsoon cycles. Similar seasonal trends were also observed by Sheu and colleagues (Sheu et al., 2010) at the high elevation site in Taiwan of Lulin, though overall concentrations were lower than those observed in Taipei (Tseng et al., 2010).

The SCS is the largest marginal sea in the tropicalsubtropical western North Pacific. The SCS is adjacent to major atmospheric $\mathrm{Hg}$ emission source regions (e.g., East Asian continent and Indochina peninsula). The SCS is particularly subjected to the forcing of monsoons and many tropical cyclones. Most notably, the monsoon cycle drives prevailing winds in the summer from the southwest and in winter mostly from the northeast. It was reported that, during the winter, air pollutants and dusts from the northern China might be transported southwardly to the SCS by the prevailing northeast winds (Duce et al., 1991; Wang et al., 2005). To assess this potential impact with respect to $\mathrm{Hg}$, we have determined the GEM concentration in the atmosphere during seasonal oceanographic cruises in the SCS to the South East Asian Time-series Study (SEATS) station $\left(18^{\circ} \mathrm{N}, 116^{\circ} \mathrm{E}\right.$, Fig. 1$)$. We have combined this concentration data with remotely sensed temperature and wind speed as well as NOAA-HYSPLIT backward air trajectory analysis to examine the time-series variability in gaseous elemental $\mathrm{Hg}$ (GEM) over the northern SCS. In this study, the seasonal GEM variations between 2003 and 2005 in the atmosphere of the Northern South China Sea (SCS) are presented for the first time. The dataset offers a unique opportunity to study the potential outflow of $\mathrm{Hg}$ associated with northeast monsoon from China in a low latitude subtropical marginal sea.

\section{Experimental}

\subsection{Study area}

The SCS (Fig. 1) is one of the largest semi-enclosed marginal seas in the world. It covers an area of $3.5 \times 10^{6} \mathrm{~km}^{2}$ with an average depth of $1200 \mathrm{~m}$. The main basin of the SCS extends from $\sim 22^{\circ} \mathrm{N}$ along the shelves of southern China to the equator along the Sunda shelf north of Borneo and 


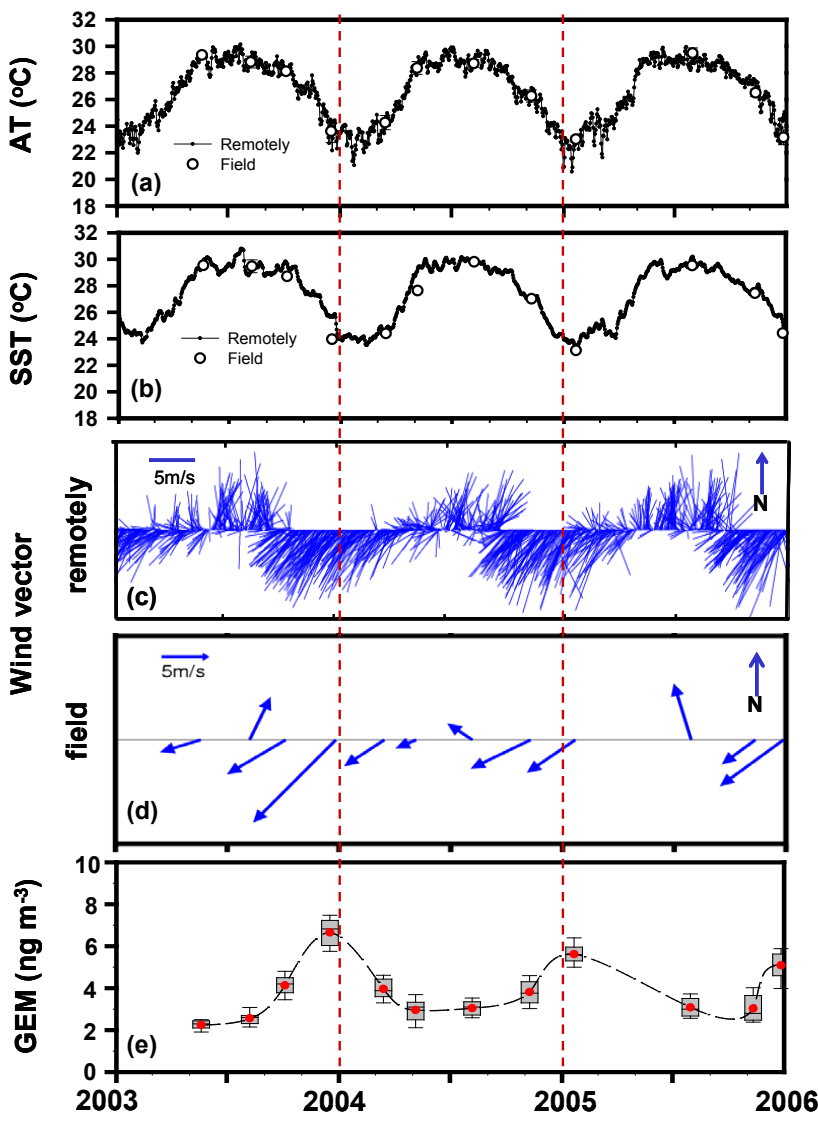

Fig. 2. Time-series of records obtained for the SEATS station over northern South China Sea during the study period from Aug. 2003 to Dec. 2005. (a) Remotely sensed surface air temperature (AT • and field observed, o); (b) Remotely sensed sea surface temperature (SST • and field observed, o); (c) remotely sensed wind vector and speed (WS); (d) field observed wind data; (e) averaged GEM. Boxes represent interquartile ranges, bars delineate upper and lower $10 \%$, and the center line is the median; means are shown by red $\bullet$.

from about $108^{\circ} \mathrm{E}$ along the coast of the Indochina peninsula to $120^{\circ} \mathrm{E}$ along the western coast of the Philippine islands. Thus, almost the entire Sea lies within the tropical zone. The SEATS station is located in the tropical northern SCS at $18^{\circ} \mathrm{N}, 116^{\circ} \mathrm{E}$. The surface air and water are warm year round. The seasonal variations in sea surface temperature are small (Fig. 2a, b) and the upper water column is well stratified at all times (Tseng et al., 2005, 2007, 2009a, b).

The Taiwanese National Center for Ocean Research (NCOR) has been operating the SEATS program, featuring regular sampling in the northern SCS since 1999 (Tseng et al., 2005, 2007). This location is far enough away from the land/continent $(\sim 400 \mathrm{~km})$ so that the signals observed will be broadly integrative and not local. The goal of the SEATS program is to generate long-term datasets that will facilitate the examination of the biogeochemistry of this important marginal sea (Tseng et al., 2009a, b). Of particular interest and importance is the examination of the impact of atmospheric forcing (e.g., monsoons) on the long-term and interannual variability in ocean biogeochemistry.

\subsection{Sampling program with GEM determination}

The SEATS station was occupied with on-board atmospheric and water $\mathrm{Hg}$ sampling 12 times between May 2003 and December, 2005 in approximately seasonal intervals aboard R/V Ocean Researcher-I (OR1-cruise numbers 682, 19-20 May 2003; 690, 5-10 August 2003; 696, 3-7 October 2003; 705, 14-19 December 2003; 711, 10-18 March 2004; 717, 3-8 May 2004; 726, 3-8 August 2004; 736, 5-11 November 2004; 743, 20-22 January 2005; 773, 7-14 November 2005; 23-30 December 2005) and Fishery researcher-1 (34, 26 July-1 August 2005). During the cruise runs, uncontaminated marine air samples for the GEM measurements were collected underway from the bow of the ship ca. $15 \mathrm{~m}$ above the sea surface and additionally collected at the SEATS station while the ship was facing into the wind and moving slowly.

The sampling and analysis of GEM were carried out on board by an on-line semi-automatic GEM analyzer (GEMA), combining flow-injection, and gold amalgamation preconcentration techniques together with cold vapor atomic fluorescence detection (Tekran 2500; Tseng et al., 2010, Fig. S1 in the Supplement). The GEMA was previously validated by comparison with the standard gold-amalgamation protocol (Fitzgerald and Gill, 1979) at the campus of National Taiwan University (Taipei, Taiwan), which showed good agreement (Tseng et al., 2010). The GEMA allows for reliable GEM determination in ambient air with high recoveries of $110 \pm 10 \%$ (from spiked gas standards, $\mathrm{n}=6$ ), a low detection limit of $0.1 \mathrm{ng} \mathrm{m}^{-3}$ for a sample volume of $10 \mathrm{~L}$ and an excellent reproducibility (r.s.d. $\leq 5 \%, n=6$ ). The details in related operation and reliability/performance of the GEMA refer to the paper by Tseng et al., 2010 (Table S1 in the Supplement). The sampling rate was set on the constant flow in the range of $0.5-1 \mathrm{~L} \mathrm{~min}^{-1}$ with adjustable analysis frequencies from $15 \mathrm{~min}$ to hours, depending on the cruise conditions, and monitored with Sierra mass flow meters. Data quality was verified via periodic calibrations by manual gas standard injections every $24 \mathrm{~h}$ (from 20 to $300 \mathrm{pg}, r^{2}=0.992-0.999$, $n=5$ ) and via single standard additions (ca. $100 \mathrm{pg}$ ) after every sample measurement to correct the detector reading.

\subsection{Other ancillary data}

The dissolved elemental Hg (DEM) sampling and measurements were performed on board during the same cruises at the SEATS site. The ultraclean sampling and analytical techniques were followed in this study as mentioned by Tseng et al. (2003, 2004). Briefly, sea surface waters were sampled by dipping acid-cleaned 2-L Teflon bottles off the front of the boat while slowly moving forward into the wind. Samples were collected once every 3-6 hours per day (4-8 
samples per day) to obtain a more representative mean for that cruise period. Once collected, the bottles were capped, double-bagged, and stored in coolers under ice. The analysis for DEM was immediately carried out by an on-line semiautomatic DEM analyzer (DEMA), coupling the two-stage $\mathrm{Au}$-amalgamation and flow-injection techniques with atomic fluorescence detection (Tseng et al., 2003, 2004). This analytical framework provides rapid, precise, and accurate analyses. DEM averaged $10 \pm 1 \mathrm{pg}(n=6)$ in procedural blanks with a low detection limit, measure precision and spike recovery (about $30 \mathrm{fM} ; \pm 5 \% ; 100 \pm 5 \%, n=6$ ) during the cruise period. Further details in related operation and reliability/performance of the DEMA can be found in Tseng et al. (2003, 2004).

The daily average air temperature (AT) at $2 \mathrm{~m}$ above the sea surface, sea surface temperature (SST) and daily wind vector at $10 \mathrm{~m}$ height for the SEATS station between January, 2003 and December, 2005 were retrieved from NOAA NCEP/NCAR Reanalysis dataset (http://www.cdc.noaa.gov/ data/gridded/data.ncep.reanalysis.html). The NCEP-AT, SST and -WS all agreed well with ship-board observations (Fig. 2a, b, c), indicating the remotely sensed data used here are reliable (Tseng et al., 2005, 2009a, b).

Backward air trajectories were generated using the HYSPLIT model (HYbrid Single-Particle Lagrangian Integrated Trajectory) of NOAA. HYSPLIT allows a wide range of simulations related to atmospheric transport, dispersion and sources of hazardous air pollutants (Draxler and Rolph, 2003). For our purposes, the model was used to generate three-day-backward air trajectories at $100 \mathrm{~m}$ altitude above sea level centered on the SEATS site.

\subsection{Flux estimates}

The exchange flux, $F$, of $\mathrm{Hg}^{0}$ at the air-seawater interface is estimated using the equation: $F=K \times(\mathrm{DEM}-\mathrm{GEM}) / H$, where $F\left(n \mathrm{n} \mathrm{m}^{-2} \mathrm{~d}^{-1}\right)$ is the volatile $\mathrm{Hg}^{0}$ flux into $(-)$ or out $(+)$ of the SCS, $K$ is the transfer velocity $\left(\mathrm{md}^{-1}\right)$, $H$ is the dimensionless Henry's Law constant, DEM and GEM are the dissolved and gaseous $\mathrm{Hg}^{0}$, respectively. We compared two formulations for the transfer velocity, $K$, including that by Liss and Merlivat $(1986 ; K=0.17$ $u_{10}\left(\mathrm{Sc}_{\mathrm{Hg}}^{T} / 660\right)^{-1 / 2}\left[0<u_{10}<3.6\right] ; K=\left(2.85 u_{10}-9.65\right)$ $\left.\left(\mathrm{Sc}_{\mathrm{Hg}}^{T} / 660\right)^{-1 / 2}\left[13>u_{10}>3.6\right]\right)$ and Wanninkhof (1992; $\left.K=0.39 u_{10}^{2}\left(\mathrm{Sc}_{\mathrm{Hg}}^{T} / 660\right)^{-1 / 2}\right)$, hereafter referred to as LM86 and W92, where $u_{10}$ refers to the wind speed at $10 \mathrm{~m}$ height over the water $\left(\mathrm{m} \mathrm{s}^{-1}\right)$ and $\mathrm{Sc}_{\mathrm{Hg}}^{T}$ is the temperature- and salinity-dependant dimensionless Schmidt number for $\mathrm{Hg}^{0}$ normalized to that for $\mathrm{CO}_{2}\left(660\right.$, at $\left.25^{\circ} \mathrm{C}\right)$ at a given temperature $T$. The transfer velocities calculated by the LM86 and W92 show the lower and upper limits, respectively, of uncertainty. Therefore, it is useful to present the potential ranges of air-sea $\mathrm{Hg}$ exchange fluxes simply bounded by the Liss and Merlivat and Wanninkhof models in this study. The values for $\mathrm{H}$ are from a recent re-analysis of this parameter (Andersson et al., 2008).

\section{Results and discussion}

\subsection{Seasonal patterns in GEM and related environmental conditions}

GEM data from the May 2003 to December 2005 surveys as well as remotely sensed AT, SST, and wind speed during the cruises are presented in Table 1 and Fig. 2 (and in greater detail in Fig. S2 in the Supplement), and distinctive seasonal patterns were observed in these three parameters. AT oscillated seasonally between winter $\left(21-24^{\circ} \mathrm{C}\right)$ and summer $\left(28-30^{\circ} \mathrm{C}\right.$; Fig. 2a). SST also varied between a maximum of $\sim 31^{\circ} \mathrm{C}$ in the summer to a minimum of $\sim 23^{\circ} \mathrm{C}$ in the winter (Fig. 2b). The variations in SST stayed closely in phase with those in AT although the amplitude was slightly reduced. The wind pattern was governed by the monsoons: the northeast monsoon in the winter and the southwest monsoon in the summer (Fig. 2c). The WS during the northeast monsoon, averaging $9 \mathrm{~m} \mathrm{~s}^{-1}$, was higher than during the southwest monsoon (averaging $\left.6 \mathrm{~m} \mathrm{~s}^{-1}\right)$. The lowest WS $\left(<4 \mathrm{~m} \mathrm{~s}^{-1}\right)$ was found in the inter-monsoonal periods in the late spring (April to May) and the early fall (September to October). The wind patterns of the northeast and the southward wind were observed during the 12 cruises, corresponding to the monsoon wind patterns (Fig. 2c, d). There was a winter maximum of the GEM (4-6 $\mathrm{ng} \mathrm{m}^{-3}$ ) associated with northeast winds and a minimum $\left(2-3 \mathrm{ng} \mathrm{m}^{-3}\right)$ in late spring and summer with southward wind (Fig. 2e, Fig. S2 in the Supplement, Table 1).

Seasonal hourly mean GEM concentrations showed diel variations, especially in warm seasons (Fig. 3, greater detail in Fig. S3 in the Supplement). Generally, diel variability in GEM exhibited minimum concentrations in the early morning before sunrise and maximum concentrations around solar noon (1000-1400 local standard time). However, the diel cycle was seasonally modulated reaching a maximum amplitude (difference between daily $\mathrm{Hg}^{0}$ minima and maxima) of $0.8-1 \mathrm{ng} \mathrm{m}^{-3}$ for summer and autumn. At least some of the seasonality of the diel cycling could be due to seasonal changes in evasion from sea to air, as this flux reaches a maximum summer and autumn (Fig. 4), when the diel cycling is also most pronounced. However, for evasion to explain all the variation, the marine boundary layer would have to be no deeper than about $100 \mathrm{~m}$, which is likely too shallow. Thus, other factors must contribute to the diel cycle and its seasonality than just evasion.

Higher seasonal average DEM concentrations were observed for summer and autumn $\left(30 \pm 3 \mathrm{ng} \mathrm{m}^{-3} ; n=3\right.$ and $23 \pm 5 ; n=3$, respectively), while lowest in winter $\left(13 \pm 4 \mathrm{ng} \mathrm{m}^{-3} ; \mathrm{n}=3\right)$ and resulting in undersaturation $(\sim 81 \pm 12 \%)$ relative to atmospheric equilibrium. Consequently, DEM evasion is indicated for summer 
Table 1. Statistical summary of GEM concentrations with environmental variables in the northern SCS obtained during the study period from 2003 to 2005 .

\begin{tabular}{|c|c|c|c|c|c|c|c|c|c|c|}
\hline \multirow[t]{2}{*}{ Cruise } & \multirow[t]{2}{*}{ Period } & \multicolumn{5}{|c|}{$\begin{array}{c}\text { GEM } \\
\left(\mathrm{ng} \mathrm{m}^{-3}\right)\end{array}$} & \multicolumn{2}{|c|}{ Wind Vector } & \multirow[t]{2}{*}{$\begin{array}{l}\text { Sea Surface Air } \\
\text { Temp. }\left({ }^{\circ} \mathrm{C}\right)\end{array}$} & \multirow[t]{2}{*}{$\begin{array}{l}\text { Sea Surface } \\
\text { Temp. }\left({ }^{\circ} \mathrm{C}\right)\end{array}$} \\
\hline & & Average & Median & Range & Daytime $^{1}$ & Nighttime & V. $\left(\mathrm{m} \mathrm{s}^{-1}\right)$ & Dir./Groups 2 & & \\
\hline OR1_682 & $19 / 05-20 / 05 / 2003$ & $2.2 \pm 0.2(n=20)$ & 2.3 & $1.9-2.6$ & $2.4 \pm 0.1$ & $2.0 \pm 0.1$ & 4.5 & $71 / \mathrm{II}$ & $29.3 \pm 0.2$ & $29.9 \pm 0.1$ \\
\hline OR1_690 & 05/08-10/08 & $2.6 \pm 0.3(n=41)$ & 2.6 & $2.0-3.3$ & $2.8 \pm 0.3$ & $2.4 \pm 0.2$ & 5.8 & 203/I & $28.8 \pm 0.4$ & $29.5 \pm 0.1$ \\
\hline OR1_696 & $03 / 10-07 / 10$ & $4.0 \pm 0.6(n=28)$ & 4.1 & $2.7-5.4$ & $4.2 \pm 0.6$ & $3.8 \pm 0.2$ & 7.4 & $56 / \mathrm{III}$ & $28.1 \pm 0.2$ & $28.7 \pm 0.1$ \\
\hline OR1_705 & $14 / 12-20 / 12$ & $6.7 \pm 0.7(n=38)$ & 6.8 & $5.4-7.6$ & $6.9 \pm 0.6$ & $6.7 \pm 0.5$ & 12.2 & $41 / \mathrm{III}$ & $23.6 \pm 0.8$ & $24.0 \pm 0.1$ \\
\hline OR1_711 & $10 / 03-18 / 03 / 2004$ & $4.0 \pm 0.5(n=45)$ & 3.9 & $2.6-5.2$ & $4.3 \pm 0.4$ & $3.7 \pm 0.4$ & 5.8 & 53/III & $24.3 \pm 0.5$ & $23.4 \pm 0.1$ \\
\hline OR1_717 & 03/05-08/05 & $3.0 \pm 0.6(n=40)$ & 3.1 & $1.5-3.9$ & $3.1 \pm 0.4$ & $2.9 \pm 0.5$ & 3.4 & 65/II-III & $28.4 \pm 0.5$ & $27.6 \pm 0.1$ \\
\hline OR1_726 & 03/08-08/08 & $3.0 \pm 0.3(n=17)$ & 3.1 & $2.6-3.6$ & $3.2 \pm 0.3$ & $2.8 \pm 0.1$ & 4.3 & $127 / \mathrm{I}$ & $28.7 \pm 0.3$ & $29.8 \pm 0.1$ \\
\hline OR1_736 & $05 / 11-11 / 11$ & $3.8 \pm 0.6(n=30)$ & 3.8 & $2.9-4.8$ & $4.1 \pm 0.5$ & $3.4 \pm 0.3$ & 7.2 & 61/III & $26.3 \pm 0.5$ & $27.0 \pm 0.1$ \\
\hline OR1_743 & $20 / 01-24 / 01 / 2005$ & $5.6 \pm 0.5(n=21)$ & 5.7 & $5.1-6.8$ & $5.8 \pm 0.3$ & $5.6 \pm 0.2$ & 7.5 & $52 / \mathrm{III}$ & $23.0 \pm 0.2$ & $23.1 \pm 0.1$ \\
\hline FR1_S34 & $26 / 07-01 / 08$ & $3.0 \pm 0.4(n=24)$ & 3.0 & $2.3-3.8$ & $3.3 \pm 0.3$ & $2.7 \pm 0.2$ & 6.0 & $165 / \mathrm{I}$ & $29.5 \pm 0.4$ & $29.5 \pm 0.1$ \\
\hline OR1_773 & $07 / 11-14 / 11$ & $3.0 \pm 0.6(n=18)$ & 2.9 & $2.4-4.1$ & $3.6 \pm 0.5$ & $2.8 \pm 0.4$ & 7.6 & 50/II-III & $26.5 \pm 0.3$ & $27.4 \pm 0.1$ \\
\hline OR1_780 & $23 / 12-30 / 12$ & $5.1 \pm 0.5(n=25)$ & 5.1 & $4.2-5.9$ & $5.2 \pm 0.3$ & $4.9 \pm 0.2$ & 9.7 & $50 / \mathrm{III}$ & $23.2 \pm 0.5$ & $24.4 \pm 0.1$ \\
\hline
\end{tabular}

${ }^{1}$ Daytime denotes the time period from 6:01 am to 6:00 p.m.; Nighttime is from 6:01 p.m. to 6:00 a.m.

2 Dir./Groups denote wind direction and source region of air mass, respectively.

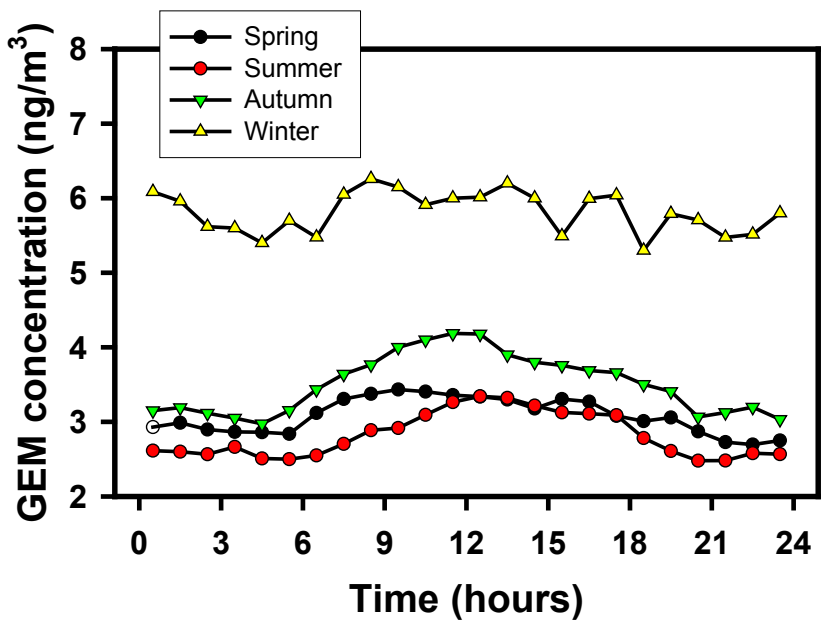

Fig. 3. Seasonal changes in diel GEM cycle over the northern SCS based on seasonal average concentrations for each hour. Each season is the average of diel data from 3 cruises.

$\left(\sim 60 \pm 10(\mathrm{LM} 86)-110 \pm 20\right.$ (W92) $\left.\mathrm{ng} \mathrm{m}^{-2} \mathrm{~d}^{-1}\right)$ and autumn $(\sim 80 \pm 20-160 \pm 40)$ but invasion of $\mathrm{Hg}^{0}$ is implied for winter $(-20 \pm 10$ to $-40 \pm 30$; Fig. 4e). Assuming a marine boundary layer thickness of $100 \mathrm{~m}$, evasion of $\mathrm{Hg}$ from the SCS contributed significant amounts of $\mathrm{Hg}^{0}$ to the atmosphere during the warmer months. For example, given seasonal averaged evasion fluxes of $20,90,120 \mathrm{ng} \mathrm{m}^{-2} \mathrm{~d}^{-1}$ for spring, summer and autumn, respectively, the evasional contribution to the daily and seasonally averaged GEM concentrations were $0.3,0.8$ and $1 \mathrm{ng} \mathrm{m}^{-3}$, representing 9, 29 and $26 \%$ of the boundary layer mass of $\mathrm{Hg}^{0}$. It must be noted that $100 \mathrm{~m}$ is a relatively shallow boundary layer depth, and therefore these contributions likely represent upper estimates of the impact of evasion on GEM over the SCS. However, these values are of the same order as the diel cycling of GEM and exhibit the same seasonal trends (Fig. 3). It is also important to note that while the diel variability in GEM may be explained by evasional losses of $\mathrm{Hg}$ from the SCS, the magnitude of diel variability attributable to evasion is not as large as the seasonal difference, postulated to originate from continental sources. This variability is discussed below.

\subsection{Seasonal GEM changes related to Monsoon cycling}

The seasonal distributions of GEM varied significantly over the northern SCS (Figs. 2e, 4c). Distribution patterns show clearly elevated GEM values in the winter months under strong northeast monsoon with prevailing northeast wind for December $(5.9 \pm 1.1, n=2)$, January $(5.6 \pm 0.5, n=1)$ and presumably February. Lower GEM values occurred from May (2.6 $\pm 0.5, n=2)$ to August $(2.8 \pm 0.3, n=2)$ under inter-monsoon and summer monsoon. These data suggest that the seasonal variation of GEM is related to the source of GEM controlled by East Asian monsoons with the prevailing northeast wind in winter and southwest in summer (Figs. 2c, e and $4 b, c)$. Further evidence is shown in Fig. 5a, b in the form of rose diagrams for the relationship between the DEM concentrations and wind speed governed by the monsoon cycling.

The GEM concentrations in spring, summer, autumn and winter averaged $3.3 \pm 0.9(n=3), 2.8 \pm 0.2(n=3)$, $3.8 \pm 0.3(n=3)$, and $5.7 \pm 0.2(n=3) \mathrm{ng} \mathrm{m}^{-3}$, respectively (Fig. 4c). The concentrations in summer and late spring $(2.6 \pm 0.5, n=2)$ averaged lower than those in early spring $(4.0 \pm 0.5, n=1)$, autumn and winter. The seasonal differences were statistically significant $(p<0.001)$ and also significant (3 times greater) compared to the estimated daily variations in each season (Fig. S4 in the Supplement). Similar seasonal variability was also reported at mid-latitude Canadian and European coastal sites (Kellerhals et al., 2003; Kock et al., 2005; Soerensen et al. 2010a, b). However, seasonal 

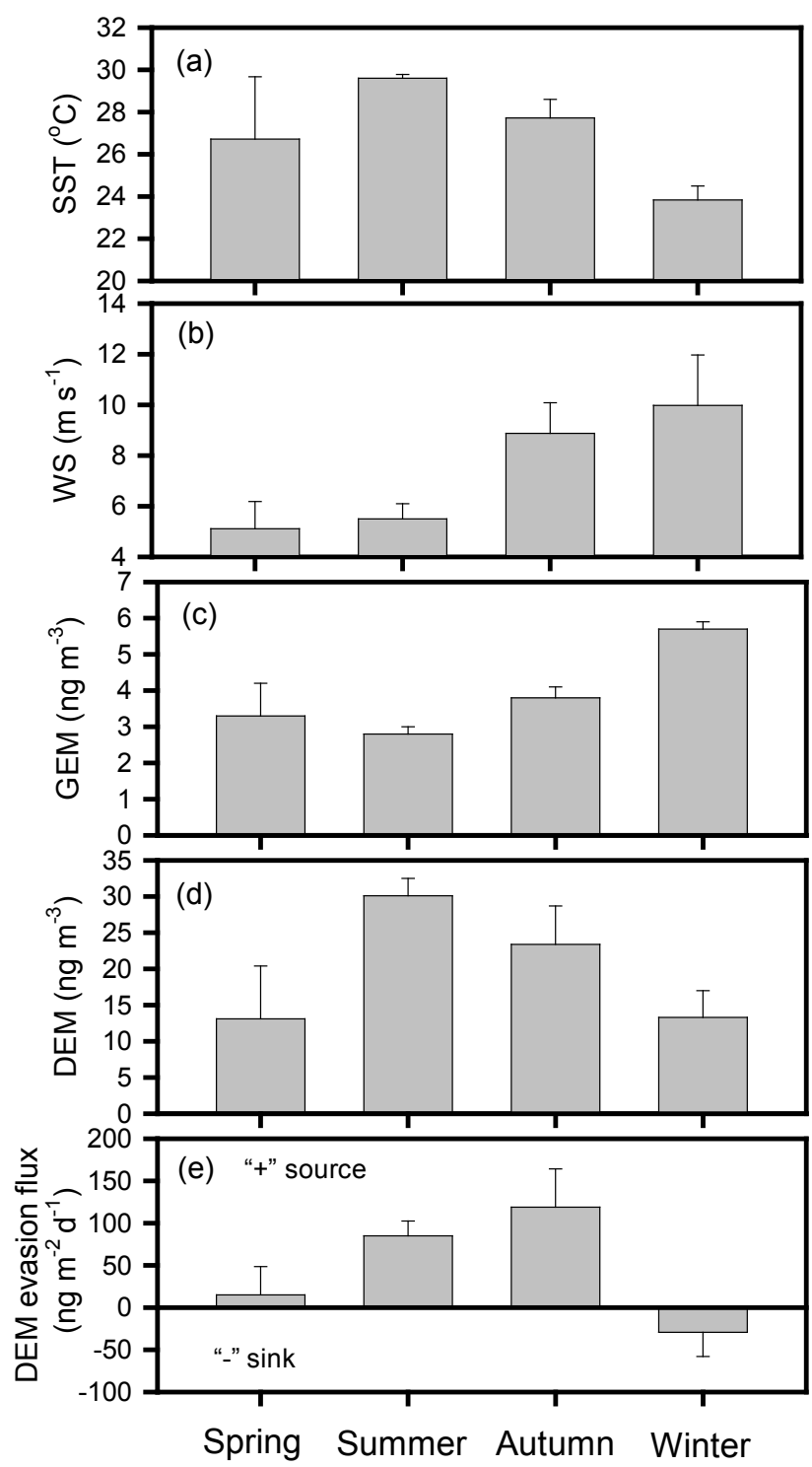

Fig. 4. Summary of seasonal average data for (a) SST; (b) WS; (c) GEM; (d) DEM and (e) air-sea $\mathrm{Hg}^{0}$ exchange flux (i.e., averaged the values obtained from LM86 and W92) between 2003 and 2005 at SEATS station in the SCS. Each seasonal bar has an average of 3 cruises with an error of $\pm 1 \mathrm{SD}(n=3)$.

differences of the GEM observed over the northern SCS are mostly explained by the sources of air masses related to monsoon cycle and the burning of fossil fuel instead of seasonal oxidation processes (Kellerhals et al., 2003; Kock et al., 2005) and seasonal SST changes in the SCS. This pattern is observed in other trace gases as well, particularly those like non-methane hydrocarbons and halocarbons that trace anthropogenic sources (e.g., Blake et al., 1997). The seasonal GEM distribution is totally opposite to the pattern of SST (Fig. 2b, e), indicating the GEM seasonality is not determined by the seasonal SST changes which may control the formation of DEM (Xiao et al., 1999; Tseng et al., 2004; Tseng and Lamborg, 2012). The observed high DEM concentrations in summer and autumn lead to elevated Hg evasion which mainly account for the GEM daily variation as mentioned above (Fig. 4). Fossil fuel combustion for economic and industrial uses and domestic heating from Mainland China inland is, however, a mercury source which is greatest during the colder seasons (Wang et al., 2000; Wu et al., 2006). Thus, air masses with high $\mathrm{Hg}$ levels generated from China tend to be exported to the SCS during the cold season as a result of the winter monsoon.

Regardless of season, GEM concentrations in the air of northern SCS tend to be much elevated compared to the global background values $\left(1.5-2.2 \mathrm{ng} \mathrm{m}^{-3}\right)$ at the same latitude $\left(18^{\circ} \mathrm{N}\right.$ to $\left.22^{\circ} \mathrm{N}\right)$ in the Pacific Ocean and Atlantic Ocean (Fitzgerald, 1995; Lamborg et al., 2002; Temme et al., 2003). Additionally, the GEM concentrations in the northern SCS region are higher than those observed in the marginal seas such as the Mediterranean Sea $\left(0.8-2.3 \mathrm{ng} \mathrm{m}^{-3}\right.$; Pirrone et al., 2003), the Baltic Sea (1.4-2.0 $\mathrm{ng} \mathrm{m}^{-3}$; Urba et al., 2000), North Sea (1.2-2.0 $\mathrm{ng} \mathrm{m}^{-3}$; Wängberg et al., 2007). However, the GEM results in spring and summer in SCS are comparable with observations made in the Northwest Pacific Ocean between Japan and Hawaii collected between May and June $2002\left(2.5 \pm 0.5 \mathrm{ng} \mathrm{m}^{-3}\right.$; Laurier et al., 2003) and in the northern SCS in August 2007 (2.6 $\pm 1.1 \mathrm{ng} \mathrm{m}^{-3}$; Fu et al., 2010). During spring, GEM results ranged from 1.5 to $5.2 \mathrm{ng} \mathrm{m}^{-3}$ (Table 1) were also similar to those observed in seas near Korea and Japan in $2001\left(1.6-6.3 \mathrm{ng} \mathrm{m}^{-3}\right.$; Friedli et al., 2004) and in 2004 (1.4-4.7 $\mathrm{ng} \mathrm{m}^{-3}$; Jaffe et al, 2005). Furthermore, higher GEM concentrations were observed, similar to those in the East China Sea $\left(\sim 3-6.3 \mathrm{ng} \mathrm{m}^{-3}\right)$ and North Pacific Ocean $\left(\sim 3-3.7 \mathrm{ng} \mathrm{m}^{-3}\right)$, due to industrial plumes from China (Friedli et al., 2004). Overall, although the SCS is further south than the ECS, our GEM results show the SCS is indeed impacted by regional sources year round, and especially during the winter.

The concentration of GEM observed at SEATS was comparable to, or lower than, observations made at land-based sites in Mainland China. For example, near Hong Kong (Li et al., 2011) and Shanghai (Friedli et al., 2011), the concentration of GEM peaked at 19 and $60 \mathrm{ng} \mathrm{m}^{-3}$, respectively during the periods of study. These values are substantially higher than we observed at SEATS. This suggests that while GEM was often quite high at SEATS, it represents a reasonable mixing of highly impacted air masses with lower concentrations from more rural and marine regions.

It is also interesting to note that the concentrations of GEM measured at sea level and over the SCS in this study are generally two times higher than those observed at the high elevation Lulin monitoring station in Taiwan (Sheu et al., 2010). Thus, while the Lulin data are important for understanding regional impacts on the free troposphere over East Asia, that dataset is clearly not relevant for understanding the depositional and air-sea exchange dynamics of the SCS 

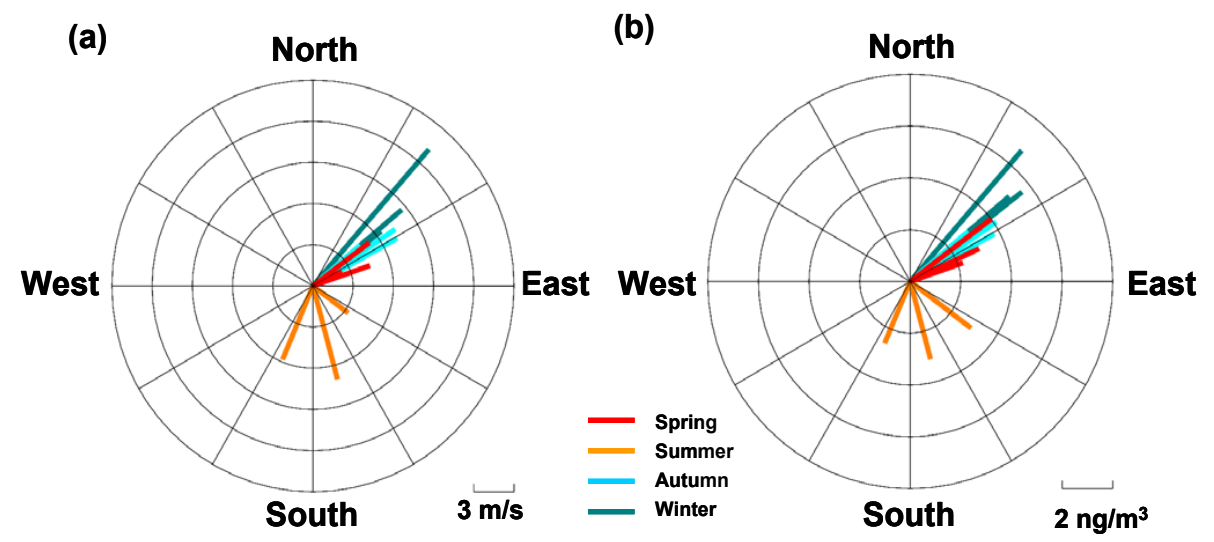

Fig. 5. Rose diagrams of (a) averaged wind vector and (b) GEM values with wind direction between 2003 and 2005 over the northern SCS.

and indicates that for marginal seas close to large sources of $\mathrm{Hg}$, the marine boundary layer appears decoupled in some respects from that of the wider troposphere.

\subsection{Air trajectories with source implications}

In order to more firmly attribute the variations in GEM concentration to monsoon climatology, air mass backward trajectory analysis was performed using the HYSPLIT model of NOAA (Draxler and Rolph, 2003). Three-day backward air trajectories starting at the SEATS station of all cruises marked in spring, summer, autumn and winter with average GEM concentrations are given in Fig. 1. Briefly, GEM concentrations over the northern SCS are determined by source influencing with a pronounced dependence on the air mass movement pattern. In this study, $\mathrm{Hg}$ source regions can be characterized by three major groups according to air mass movement patterns. In group I, corresponding to the summer southwest monsoon, the back trajectories on 8 August 2003 (OR1-696), 5 August 2004 (OR1-726) and 29 July 2005 (FR1-34) all came from the northeastern Indian Ocean and then passed over the Indochina (Fig. 1). The GEM concentrations measured at SEATS from these trajectories tended to be lower than the average in all measurements of the SCS, but significantly higher than the global background. The elevated summer GEM results $\left(2.0-3.8 \mathrm{ng} \mathrm{m}^{-3} ; n=82\right)$ indicate the export of atmospheric $\mathrm{Hg}$ from the Indochina peninsula (with concentrations about $2.0-4.0 \mathrm{ng} \mathrm{m}^{-3}$; Nakagawa and Hiromoto, 1997) although the air mass originally came from Indian Ocean with presumably low $\mathrm{Hg}$ emissions. This further suggests the influence of regional human-induced and biomass burning $\mathrm{Hg}$ emissions from Indochina peninsula (Fig. S5). In group III in winter, the backward trajectory analyses show the air parcels of 17 December 2003 (OR1-705), 21 January 2005 (OR1-743) and 26 December 2005 (OR1780) came from northeastern (i.e., Liaoning province), northern (i.e., Hebaei, Shanxi provinces) and eastern China (i.e., Shandong, Jiangsu, Shanghai, Zhejiang, Jiangxi provinces), highly industrialized regions, and which were elevated in GEM (Figs. 2e, 4c). The winter maxima of the GEM could be attributed to regional anthropogenic emissions from Mainland China (Fig. S5). In early spring and autumn, the backward trajectory analysis shows the surface air masses from passed over northern China, Korea and Japan in a way similar to those observed in winter (Fig. 1). Nevertheless, the northeast monsoon was weakening and the GEM concentrations were lower than those in winter. The lowest GEM was observed in group II during OR1-682 in May 2003 under inter-monsoon periods. During that cruise, the air mass originated from the Western Pacific Ocean and then pass through Philippine Islands, and not from Mainland China as on the other two spring cruises (Fig. 1). Thus, seasonal GEM changes over the northern SCS are apparently determined by the origin of the air masses and the sources of $\mathrm{Hg}$ within those regions, as governed by the East Asian monsoons. This is in agreement with previously observed and model results, which highlighted the $\mathrm{Hg}$ distribution in surrounding regions downwind via long-range transport seriously impacted by anthropogenic emissions from China (Friedli et al., 2004; Jaffe et al, 2005; Strode et al., 2008; Obrist et al., 2008). However, in comparison with atmospheric GEM levels presented here, $\mathrm{Hg}$ concentrations in the SCS were apparently underestimated by model studies, likely due to underestimations of anthropogenic and natural $\mathrm{Hg}$ emissions from East Asian countries, especially from China (Li et al., 2006, 2008).

\section{Conclusions}

Our studies in SCS reveal the prominent role of GEM in the transport of $\mathrm{Hg}$ pollution to marginal seas of East Asia surrounding China. Through the development of a time-series record, we have observed the elevated GEM (2-3 times higher than global background at the same latitude) of the region and its distinctive seasonal variation pattern principally 
associated with the export of the East Asian $\mathrm{Hg}$ emissions by the monsoon cycling. The results show the higher GEM in autumn and winter with prevailing northeast wind from China (4-6 $\mathrm{ng} \mathrm{m}^{-3}$, group III) and lower in late spring and summer with southwest wind from Indochina $\left(2-4 \mathrm{ng} \mathrm{m}^{-3}\right.$, group I) and east from the western Pacific Ocean $(\sim 2-$ $3 \mathrm{ng} \mathrm{m}^{-3}$, group II). Further, through backward air trajectory analysis we demonstrated that seasonal GEM changes over the northern SCS were primarily caused by the origin of the air masses and the sources of $\mathrm{Hg}$ within those regions, as governed by the East Asian monsoons. The spring GEM concentrations over the SCS are comparable to those observed in the temperate ocean regions surrounding Japan and Korea at the same season (Laurier et al., 2003; Friedli et al., 2004; Jaffe et al., 2005). However, there are no data reported in cold seasons in the East Asian marginal seas. Further, that evidence points to continental sources and wind monsoon direction as the factors dictating seasonal differences in GEM and this confirming this with high resolution air/water $\mathrm{Hg}^{0}$ measurements should be the priority for future study. To have a better understanding and quantification of the seasonality and long-range transportation of the GEM in seas surrounding China, more investigations through automated simultaneously air-water measurements, are needed for all other seasons of the year and for solving the issue of spatial and temporal variability to obtain a representative estimate

\section{Supplementary material related to this article is available online at: http://www.atmos-chem-phys.net/12/ 7341/2012/acp-12-7341-2012-supplement.pdf.}

Acknowledgements. We thank the officers and the crew of the R/V Ocean Research I and of the Fishery Research I. Support was provided by the National Science Council (Taiwan, Republic of China) through grant number NSC 97-2745-M-002-001-;982611-M-002-013- and through a thematic research grant titled "Atmospheric Forcing on Ocean Biogeochemistry (AFOBi)" and from the College of Science (COS\#1010023540), National Taiwan University (NTU\#101R3252) through a grant of the NTU "Aim for Top University Project" under research platform of the "Drunken-Moon Lake" scientific integration.

Edited by: A. Pszenny

\section{References}

Andersson, M. E., Gårdfeldt, K., Wängberg, I., and Stromberg, D.: Determination of Henry's law constant for elemental mercury, Chemosphere, 73, 587-592, 2008.

Blake, N. J., Blake, D. R., Chen, T. Y., Collins, J. E., Sachse, G. W., Anderson, B. E., and Rowland, F. S.: Distribution and seasonality of selected hydrocarbons and halocarbons over the western
Pacific basin during PEM-West A and PEM-West B, J. Geophys. Res.-Atmos., 102, 28315-28331, doi:10.1029/97jd02538, 1997.

Draxler, R. R. and Rolph, G. D.: HYSPLIT (HYbrid Single-Particle Lagrangian Integrated Trajectory, NOAA Air Resources Laboratory, Silver Spring MD, http://www.arl.noaa.gov/ready/hysplit4. html, 2003.

Duce, R. A., Liss, P. S., Merrill, J. T., Atlas, E. L., Buat-Menard, P. , Hicks, B. B., Miller, J. M., Prospero, J. M., Arimoto, R., Church, T. M., Ellis, W., Galloway, J. N., Hansen, L., Jickells, T. D., Knap, A. H., Reinhardt, K. H., Schneider, B., Soudine, A., Tokos, J. J., Tsunogai, S., Wollast, R., and Zhou, M.: The atmospheric input of trace species to the world ocean, Global Biogeochem. Сy., 5, 193-259, 1991.

Fitzgerald, W. F.: Is mercury increasing in the atmosphere? The need for an atmospheric mercury network (AMNET), Water Air Soil Pollut., 80, 245-254, 1995.

Fitzgerald, W. F. and Clarkson, T. W.: Mercury and monomethylmercury : present and future concerns, Environ. Health. Perspect., 96, 159-166, 1991.

Fitzgerald, W. F. and Gill, G. A.: Subnanogram determination of mercury by two-stage gold amalgamation applied to atmospheric analysis, Anal. Chem., 51, 1714-1720, 1979.

Fitzgerald, W. F., Engstrom, D. R., Mason, R. P. and Nater, E. A.: The case for atmospheric mercury contamination in remote areas, Environ. Sci. Technol., 32, 1-7, 1998.

Fitzgerald, W. F., Engstrom, D. R., Lamborg, C. H., Tseng C.-M., and Balcom, P. H.: Modern and historic atmospheric mercury fluxes in northern Alaska: Global sources and Arctic depletion, Environ. Sci. Technol., 39, 557-568, 2005.

Friedli, H. R., Radke, L. F., Prescott, R., Li, P., Woo, J. H., and Carmichael, G. R.: Mercury in the atmosphere around Japan, Korea, and China as observed during the 2001 ACE-Asia field campaign: measurements, distributions, sources, and implications, J. Geophys. Res., 109, D19S25, doi:10.1029/2003/JD004244, 2004.

Friedli, H. R., Arellano, A. F., Geng, F., Cai, C., and Pan, L.: Measurements of atmospheric mercury in Shanghai during September 2009, Atmos. Chem. Phys., 11, 3781-3788, 10, http://www.atmos-chem-phys.net/11/3781/10/.5194/acp-113781-2011, 2011.

Fu, X., Feng, X, Zhang, G., Xu, W., Li, X., Yao, H., Liang, P., Li, J., Sommar, J., Yin, R., and Liu, N.: Mercury in the marine boundary layer and seawater of the South China Sea: Concentrations, sea/air flux, and implication for land outflow, J. Geophys. Res., 115, D06303, doi:10.1029/2009JD012958, 2010.

Guo, Y. N., Feng, X. B., Li, Z. G., He, T. R., Yan, H. Y., Meng, B., Zhang, J. F., and Qiu, G.: Distribution and wet deposition fluxes of total and methyl mercury in Wujiang reservoir Basin, Guizhou, China, Atmos. Environ., 42, 7096-7103, 2008.

Holmes, C. D., Jacob, D. J., Corbitt, E. S., Mao, J., Yang, X., Talbot, R., and Slemr, F.: Global atmospheric model for mercury including oxidation by bromine atoms, Atmos. Chem. Phys., 10, 12037-12057, doi:10.5194/acp-10-12037-2010, 2010.

Jaffe, D., Prestbo, E., Swartzendruber, P., Weiss-Penzias, P., Kato, S., Takami, A., Hatakeyama, S., and Kajii, Y. Export of atmospheric mercury from Asia, Atmos. Environ., 39, 3029-3038, 2005.

Kellerhals, M., Beauchamp, S., Belzer, W., Blanchard, P., Froude, F., Harvey, B., McDonald, K., Pilote, M., Poissant, L., Puckett, 
K., Schroeder, B., Steffen, A., and Tordon, R.: Temporal and spatial variability of total gaseous mercury in Canada: results from the Canadian Atmospheric Mercury Measurement Network (CAMNet), Atmos. Environ., 37, 1003-1011, 2003.

Kock, H. H., Bieber, E., Ebinghaus, R., Spain, T. G., and Thees, B.: Comparison of long-term trends and seasonal variations of atmospheric mercury concentrations at the two European coastal monitoring stations Mace Head, Ireland, and Zingst, Germany, Atmos. Enviorn., 39, 7549-7556, 2005.

Lamborg, C. H., Fitzgerald, W. F., Graustein W. C., and Turekian, K. K.: An examination of the atmospheric chemistry of mercury using ${ }^{210} \mathrm{~Pb}$ and ${ }^{7} \mathrm{Be}$., J. Atmos. Chem., 36, 325-338, 2000.

Lamborg, C. H., Fitzgerald, W. F., O'Donnell, J., and Torgersen, T.: A non-steady-state compartmental model of global-scale mercury biogeochemistry with interhemispheric atmospheric gradients, Geochim. Cosmochim. Acta, 66, 1105-1118, 2002.

Laurier, F. J. G., Mason, R. P., Whalin, L., and Kato, S.: Reactive gaseous mercury formation in the North Pacific Ocean's marine boundary layer: a potential role of halogen chemistry, J. Geophys. Res., 108, 4529, doi:10.1029/2003JD003625, 2003.

Li, P. N., Woo, J. H., Carmichael, G. R., Tang, Y., Friedli, H. R., and Radke, L. F.: Regional distribution and emissions of mercury in east Asia: A modeling analysis of Asian Pacific Regional Aerosol Characterization Experiment (ACE-Asia) observations, J. Geophys. Res., 111, D07109, doi:10.1029/2005JD006381, 2006.

Li, P. N., Carmichael, G. R., Adhikary, B., Tanga, Y. H., Streets, D., Woo, J. H., Friedli, H. R., and Radke, L. F.: A regional analysis of the fate and transport of mercury in East Asia and an assessment of major uncertainties, Atmos. Environ., 42, 1144-1159, 2008.

Li, Z., Xia, C. H., Wang, X. M., Xiang, Y. R., and Xie, Z. Q.: Total gaseous mercury in Pearl River Delta region, China during 2008 winter period, Atmos. Environ., 45, 834-838, doi:10.1016/j.atmosenv.2010.11.032, 2011.

Lindqvist, O., Johansson, K., Aastrup, M., Andersson, A., Bringmark, L., Hovsenius, G., Håkanson, L., Iverfeldt, Å., Meili, M., and Timm, B.: Mercury in the Swedish environment-recent research on causes, consequences and corrective methods, Water Air Soil Pollut., 55, 33-47, 1991.

Liss, P. S. and Merlivat, L.: Air-sea gas exchange rates: introduction and synthesis, edited by: Buat-Menard, P.: The Role of Air-Sea Exchange in Geochemical Cycling, NATO ASI Series C, Math, Phys, Sci, 185, 113-128, 1986.

Mason, R. P., Fitzgerald, W. F., and Morel, F. M. M.: The biogeochemical cycling of elemental mercury: anthropogenic influences, Geochim. Cosmochim. Acta, 58, 3191-3198, 1994.

Nakagawa, R. and Hiromoto, M.: Geographical distribution and background levels of total mercury in air in Japan and neighboring countries, Chemosphere, 45, 1033-1043, 1997.

Obrist, D., Hallar, A.G., McCubbin, I., Stephens, B., and Rhan, T.: Atmospheric mercury concentrations at Storm Peak Laboratory in the Rocky Mountains: Evidence for long-range transport from Asia, boundary layer contributions, and plant mercury uptake, Atmos. Environ., 42, 7579-7589, 2008.

Pacyna, J. M., Pacyna, E. G., Steenhuisenb, F., and Wilson, S.: Mapping 1995 global anthropogenic emission of mercury, Atmos. Environ., 37, 109-117, 2003.

Pacyna, E. G., Pacyna, J. M., Steenhuisenb, F., and Wilson, S.: Global anthropogenic mercury emission inventory for 2000, Atmos. Environ., 37, 4048-4063, 2006.
Pirrone, N., Ferrara, R., Hedgecock, I. M., Kallos, G., Mamane, Y., Munthe, J., Pacyna, J. M., Pytharoulis, I., Sprovieri, F., Voudouri, A., and Wangberg, I.: Dynamic processes of mercury over the Mediterranean region: results from the Mediterranean Atmospheric Mercury Cycle System (MAMCS) project, Atmos. Evniron., 37, S21-S39, 2003.

Selin, N. E., Jacob, D. J., Yantosca, R. M., Strode, S., Jaegle, L., and Sunderland, E. M.: Global 3-D land-ocean-atmosphere model for mercury: Present-day versus preindustrial cycles and anthropogenic enrichment factors for deposition. Glob. Biogeochem. Cy., 22, GB2011, doi:10.1029/2007GB003040, 2008.

Sheu, G. R., Lin, N. H., Wang, J. L., Lee, C. T., Yang, C. F. O., and Wang, S. H.: Temporal distribution and potential sources of atmospheric mercury measured at a high-elevation background station in Taiwan, Atmos. Environ., 44, 2393-2400, doi:10.1016/j.atmosenv.2010.04.009, 2010.

Soerensen, A. L., Skov, H., Jacob, D. J., Soerensen, B. T., and Johnson, M. S.: Global concentrations of gaseous elemental mercury and reactive gaseous mercury in the marine boundary layer. Environ. Sci. Technol., 44, 7425-7430, 2010a.

Soerensen, A. L., Sunderland, E. M., Holmes, C. D., Jacob, D. J., Yantosca, R. M., Skov, H., Christensen, J. H., Strode, S. A., and Mason, R. P: An improved global model for air-sea exchange of mercury: high concentrations over the North Atlantic, Environ. Sci. Technol., 44, 8574-8580, 2010b.

Sprovieri, F., Pirrone, N., Ebinghaus, R., Kock, H., and Dommergue, A.: A review of worldwide atmospheric mercury measurements, Atmos. Chem. Phys., 10, 8245-8265, doi:10.5194/acp10-8245-2010, 2010.

Streets, D. G., Zhang, Q., and Wu, Y.: Projections of Global Mercury Emissions in 2050, Environ. Sci. Technol., 43, 2983-2988, 2009.

Strode, S. A., Jaeglé, L., Jaffe, D. A., Swartzendruber, P. C., Selin, N. E., Holmes, C., and Yantosca, R. M.: TransPacific transport of mercury, J. Geophys. Res., 113, D15305, doi:10.1029/2007JD009428, 2008.

Swain, E. B., Engstrom, D. R., Brigham, M. E., Henning, T. A., and Brezonik, P. L.: Increasing rates of atmospheric mercury deposition in mid-continental North America, Science, 257, 784-787, 1992.

Temme, C., Slemr, F., Ebinghaus, R., and Einax, J. W.: Distribution of mercury over the Atlantic Ocean in 1996 and 1999-2001, Atmos. Environ., 37, 1889-1897, 2003.

Tseng, C. M., Balcom, P., Lamborg, C., and Fitzgerald, W. F.: Dissolved elemental mercury investigations in Long Island Sound using on-line Au amalgamation-flow injection analysis, Environ. Sci. Technol., 37, 1183-1188, 2003.

Tseng C. M., Lamborg, C., Fitzgerald, W. F., and Engstrom, D. R.: Cycling f dissolved elemental mercury in Arctic Alaskan lakes. Geochimica et Cosmochim. Acta, 68, 1173-1184, 2004.

Tseng, C. M., Wong, G. T. F., Lin, I. I., Wu, C. R., and Liu, K. K.: A unique seasonal pattern in phytoplankton biomass in low-latitude waters in the South China Sea, Geophys. Res. Lett., 32, L08608, doi:10.1029/2004GL022111, 2005.

Tseng C. M., Wong, G. T. F., Chou, W. C., Lee, B. S., Sheu, D. $\mathrm{D}$ and Liu, K. K.: Temporal Variations in the carbonate system in the upper layer at the SEATS station, Deep-Sea Res. II, 54, 1448-1468, 2007. 
Tseng, C. M., Liu, K. K., Wang, L. W., and Gong, G. C.: Anomalous hydrographic and biological conditions in the northern South China Sea during the 1997-1998 El Niño and comparisons with the equatorial Pacific, Deep-Sea Res. I, 56, 2129-2143, doi:10.1016/j.dsr.2009.09.004, 2009a.

Tseng, C. M., Gong, G. C., Wang, L. W., Liu, K. K., and Yang, Y.: Anomalous biogeochemical conditions in the northern South China Sea during the El-Niño events between 1997 and 2003, Geophys. Res. Lett., 36, L14611, doi:10.1029/2009GL038252, 2009b.

Tseng, C. M., Lamborg, C., and Fitzgerald, W. F.: Development of a Novel on-Line Flow Injection Mercury Analyzer to Determine Gaseous Elemental Mercury over the Northern South China Sea, J. Anal. Atomic Spectrom., 25, 526-533, doi:10.1039/b924184a, 2010.

Tseng, C. M. and Lamborg, C.: A unique seasonal pattern in dissolved elemental mercury in the South China Sea, a tropical and monsoon-dominated marginal sea, submitted to Geophys. Res. Lett., in review, 2012.

Urba, A., Kvietkus, K., and Marks, R.: Gas-phase mercury in the atmosphere over the southern Baltic Sea coast, Sci. Total Environ., 259, 203-210, 2000.
Wang, Q., Shen, W., and Ma, Z.: Estimation of Mercury Emission from Coal Combustion in China. Environ, Sci. Technol., 34, 2711-2713, 2000.

Wang, T., Guo, H., Blake, D. R., Kwok, Y. H., Simpson, I. J., and Li, Y. S.: Measurements of Trace Gases in the Inflow of South China Sea Background Air and Outflow of Regional Pollution at Tai O, Southern China, J. Atmos. Chem., 52, 295-317, 2005.

Wängberg. I., Munthe, J., Berg, T., Ebinghaus, R., Kock, H. H., Temme, C., Bieber, E., Spain, T. G., and Stolk, A.: Trends in air concentration and deposition of mercury in the coastal environment of the North Sea Area, Atmos. Enviorn., 41, 2612-2619, 2007.

Wanninkhof, R.: Relationship between wind speed and gas exchange over the ocean. J. Geophys. Res., 97, 7373-7382, 1992.

Wu, y., Wang, S., Streets, D. G., Hao, J., Chan, M., and Jiang, J.: Trends in anthropogenic mercury emissions in China from 1995 to 2003, Environ. Sci. Technol., 40, 5312-5318, 2006.

Xiao, Z. F., Munthe, J., Schroeder, W. H., and Lindqvist, O.: Vertical Fluxes of Volatile Mercury over Forest Soil and Lake Surfaces in Sweden, Tellus B, 43, 267-279, 1991. 